\title{
IMPLEMENTATION OF THE GOVERNMENT'S DISCRETION IN INDONESIA, AUTHORITY, AND RESPONSIBILITY IN THE MANAGEMENT OF GOVERNMENT
}

\author{
Nur Ro’is,Tri Yani, Putri Mayang Sari, Dewi Ary Nurdiana Putri, Lupi Mardiansyah, \\ Ilmu Pemerintahan, Universitas Baturaja \\ nurrois@unbara.ac.id, triyani.bta123@gmail.com,putrimayangsari540@gmail.com, \\ dewiarynp013@gmail.com, lupi.mardiansyah98@gmail.com
}

\begin{abstract}
The research entitled "Implementation of the Government's Discretionary Authority and Accountability in the Administration of Government" has five problem formulations. First, how is the implementation of discretionary authority in the administration of Government? Second, there are obstacles in the exercise of discretionary authority. The third is how to overcome obstacles. Fourth, the limits of discretion in decision making. Fifth, Government Instruments. The purpose of this study was to identify and analyze the five problem formulations above. This research is qualitative descriptive The results of this study indicate that the exercise of discretionary authority in the administration of Government is a logical consequence of the welfare state where the welfare state government is a state power that is given the task and responsibility for the welfare of its citizens.

In contrast, discretionary authority does not mean that it can be used freely. However, it must follow the rules written in Law Number 30 of 2004 concerning Good Governance and Principles of Good Governance (AAUPB). The implementation of discretionary authority in the administration of Government also has several obstacles that cause the Government to be less efficient and less effective. Efforts to overcome these obstacles are not easy because they must involve all parties, namely legislative power, executive power, and judicial power. This is also, of course, requires the role of citizens. These things are to ensure the implementation of discretionary authority in the administration of Government so that it is efficient and effective in realizing people's welfare.
\end{abstract}

Keywords: Implementation of Discretionary Authority, Administration of Government, State Administration, People's Welfare.

\section{INTRODUCTION}

A. Background

The concept of discretion is present as a middle ground from the weakness of the legal system and the legal vacuum. Discretion was born from the Rechtsvinding school, which realized that legislators could not keep up with the speed of the movement of society or the very dynamic process of social development, so laws were always behind. Laws cannot be complete and cannot cover everything. There is always leemten (emptiness in the law) here, so it must be understood by legal reconstruction. So, in essence, state officials, especially regional governments, may take discretionary actions if they fulfill various requirements and the scope of the discretion itself,which has been regulated in the Government Administration Act. Local government officials need not hesitate as long as discretion is taken in the interests of the community.(Arbani, 2019)

Discretion is the freedom to decide about something in the situation at hand. Based on the dictionary of law, discretionary (Dutch) means that deciding something is not based on the provisions of the legislation or applicable law but wisdom, consideration, or justice. According to Philipus M. Hadjon, Discretion or freedom of action is the freedom to apply the rules in concrete situations, regulate the concrete situation, and act even though there are no or no explicit arrangements. (Hadjon et al., 2010)

In order to expedite the role, duties, and responsibilities of the Government in carrying out development tasks and public service tasks that are so broad and heavy, the Government is also given 
the authority in the form of freiesErmessen or discretionary. In carrying out or carrying out the development process, many state administrative officials express their various actions in the form of Ermessenfreies, such as regulations, circulars, announcements, guidelines, and so on. These actions are carried out without being based on the attribution of the authority of the laws and regulations to make or issue them.(Yuhdi, 2013)

In this modern era, discretion (freiesermessen) is significant to accelerate general welfare. Discretion becomes a means when there is a void or a vacuum for the absence of a rule in a specific mechanism when a concrete event requires an immediate decision to be made. In addition, discretion is a breakthrough to break stagnation, find shortcuts so that a program can run, or get around something to achieve the desired goal quickly. However, it should be noted that the use of discretion can create opportunities for abuse of power (abuse of power), excess of authority (detournement de pouvoir, ultravires), and arbitrary decisions (willekeur) made by state administration officials. Because of this, the law regulates its use so that it is not authoritarian. Law exists to regulate actions that are allowed and prohibited actions for state administration. Thus, all actions and authorities are limited by law.(Safudin, 2020)

According to Agus Budi Susilo, the discretion of public officials implies the freedom to interpret a text (norm) of laws and regulations by public officials according to the authority they have to make decisions and/or act in the administration of Government by complying with signs in the form of obeying the principles and provisions. Applicable law because there is still responsibility both morally and legally. The interpretation here too is that the text (norm) of the legislation as the basis for the footing of the public official provides a choice or there is a " space" that allows wisdom to be taken in order to carry out its authority, which if a policy is not taking will lead to government stagnation.(Susilo, 2015)

Discretionary authority is an authority that is not bound; what is meant here is an authority that is not based or directly bound by law (legality) and complements the law's weaknesses. The regulation of discretionary authority in law number 30 of 2014 concerning government administration, after this referred to as UUAP, aims to limit the use of discretionary authority and at the same time to provide legal protection for state administrative bodies/officials in exercising discretionary authority, considering that in practice prior to the regulation In such cases, many state administrative bodies/officials when carrying out their duties and authorities are reluctant to use discretionary authority, so that the obligation of the Government or the state to provide welfare for the community cannot run efficiently and effectively.

Principles in the application of discretiondeclare that the violation or procedural action deviation is not necessary toat issue, as long as the actionsare taken remain in the corridor of vision and missionorganization and stay within the framework ofachievement of organizational goals.(Mustafa et al., 2016)

B. Research Question

Based on the background described above, the authors formulate the problem as follows:

1. How is the exercise of discretionary authority in the administration of the Governmentin Indonesia?

2. What are the obstacles to the implementation of discretionary authority in the administration of the Government in Indonesia?

3. What are the efforts to overcome these obstacles?

4. What are the limits of Discretion in making State Administration decisions?

5. What are government instruments?

C. Research Objectives

This research aims to:

1. It knows how to implement discretionary authority in the administration of Government.

2. Knowing what the obstacles are in the implementation of discretionary authority in the administration of Government.

3. Knowing what the limits of Discretion are in making State Administration decisions

4. Knowing What is the Government Instruments

D. Literature Review

a. Overview of the Welfare State Concept

The welfare state is the antithesis of the concept of a formal/classical legal state based on the idea of carrying out 
strict supervision of the implementation of state power, especially executive power, which has been proven to abuse during the whole monarchy lot of power.(Wawan Riawan \& Tjandra, 2011)

The essence of the welfare state itself, according to WawanRiawanTjandra, as quoted by, is that the state must be actively involved in social and economic problems to ensure mutual prosperity in society. When compared to a formal/classical legal state where the state must act passively, in a modern law state or a welfare state, the state is required to act more actively. Indonesia is a country that uses the concept of a welfare state; this is explicitly regulated in the 1945 Constitution of the Republic of Indonesia, precisely in Preamble, which mandates that:

1) The state is obliged to protect all Indonesian people (citizens) and all Indonesianterritories.

2) The state is obliged to promote the general welfare.

3) The state is obliged to educate the nation's life.

The main characteristic of the concept of a welfare state is the obligation of the state to realize general welfare and, consequently, the state is actively involved in the community's social life.

There are three main principles in the concept of the welfare state:

a.Equality of opportunity

Citizens have equal opportunities to get an education and get a decent job. It also includes obtaining income following the work.

b. Even distribution of wealth

The concept of a welfare state aims to improve the welfare of its citizens. Therefore, the distribution of wealth evenly, especially to people in need, is one of the principles of the welfare state. An example is the distribution of social security for the unemployed.

c.Public responsibility

It means that the community is responsible for the rights or welfare that have been obtained and uses themcorrectly.

The welfare state can be described as the influence of human desires that hope to ensure a sense of security, tranquility, and prosperity so as not to fall into misery. This reason can be described as a driving force and a goal for humans to always seek various ways to achieve prosperity in their lives. The desire has been guaranteed in a country's Constitution, then the desire must be guaranteed, and the state is obliged to realize that desire.

b. Overview of the Legality Principle

In administrative law, the principle of legality, according to Ni'matul Huda as quoted by FarlianBelawaHurint, means that administrative bodies/officials in the administration of the state and Government must always be guided by by-laws made by people's representatives and without a legal basis. The administration office is not authorized to take any action that may affect the legal situation of the community. According to Sjachran Wet, the principle of legality means an effort to realize an integral duet in harmony between the understanding of the rule of law and the understanding of people's sovereignty based on the monodualistic principle as pillars whose nature is constitutive.(Huda, 2011)

The sovereignty of law means that the law is a legitimacy for the Government's authority; the actions of government agencies/officials must be based on the authority determined by law. While people's sovereignty means that the people are the legitimacy of the applicable law, the applicable law must be agreed upon through their representatives in parliament. The principle of legality in administrative law is also often referred to as the validity of the Government. The Government's legitimacy contains three aspects: negative aspects, positive formal aspects, and positive material aspects. The negative aspect determines that the actions of government agencies/officials must not conflict with the law; the positive formal aspects determine that government 
agencies/officials have authority as long as it is determined or based on the law. The buoyant material aspect determines that the law contains general binding rules. actions of government agencies/officials.(Ridwan, 2014)

The legality principle also has a weakness, namely actions based on legal and written laws, so when talking about the weaknesses of the legality principle, it means that at that time, we are also talking about the weaknesses of the laws and regulations themselves. The weakness of the law as written law is that it is very rigid and often lags behind developments in society. Written law is easy to create a gap between legal regulations and those they regulate. It seems to be the basis of justification for not acting based on the law as a normative institution, this kind of action is called Discretion. Discretion is often found in the executive and judicial states to realize each branch of state power's duties and functions effectively and efficiently.

c. Overview of the Discretionary Authority

Discretionary authority or free authority is an authority given to state administrative bodies whose basic regulations provide freedom for state administrative bodies/officials to interpret and determine for themselves the content of a decision to be issued. Related to this free authority, J.B.J.M. Ten Berge divides it into three kinds: freedom of interpretation, freedom of consideration, and freedom of policymaking. The freedom of interpretation shows the narrowest space for movement, the freedom to make decisions shows the broader range of motion, and the freedom to consider the display is an intermediate category. Regarding UUAP Article 1 point 9, Discretion is a decision and action determined and carried out by government officials to overcome concrete problems faced in government administrationregarding laws and regulations that provide choices, do not regulate, are incomplete, or are incomplete. Clear and government stagnation. Legally, the discretionary authority has been given to the Government precisely in Article 4 of the 1945 Constitution of the Republic of Indonesia, which states that the President holds government power according to the Constitution. This article shows that the President is given the Discretion to exercise his authority in holding government power.(Ridwan, 2014)

The discretionary authority is essentially a compliment to the weaknesses that exist in the law. However, the discretionary authority is free or unbound, and it does not mean that the discretionary authority is not subject to and obedient to the law as a form of people's sovereignty because administrative bodies or officials use the discretionary authority. State to realize what has been determined itself or, in other words, indirectly also implement the law. The importance of realizing the law is the law itself has given rights and obligations to the community so that based on the principle of responding to proper expectations, the Government must always realize it, and if the Government has appropriately realized the law for the welfare of the people, then for the people that is where the legal certainty will be.

The use of discretionary authority by the government administrative body can only be carried out in some instances. The applicable laws and regulations do not regulate it or because the existing regulations governing something are unclear. This is done in an emergency/urgent situation for the sake of the public interest stipulated in the regulation. The urgent situation in question is a situation that appears suddenly concerning the public interest, which must be resolved quickly, where the laws and regulations have not regulated it or only regulate it in general. At the same time, the notion of public interest is the interest of the nation and the state or the interests of the expected community or development, following the applicable laws and regulations. In addition, limitations or signs of indiscretion are the General Principles of Good Governance (AUPB). 
d. Overview of Governance

In administering the Government, the President is assisted by the vice president. In carrying out his duties,ministers also assist the President in charge of specific affairs in the government sector. In-state life in Indonesia, we recognize that there are 4 (four) groups of ministers: coordinating ministers, ministers who lead departments, state ministers, and junior ministers. Besides being assisted by the vice president and ministers, the President is also assisted by a set of officials who work in non-governmental organizations. departments (there are 19 nondepartmental institutions), and government levels I and II.

In the welfare state context, government affairs are also getting bigger and broader, almost covering all aspects of people's lives, but that does not mean that all aspects of people's lives are government affairs. There are at least 3 (three) criteria to determine that it is a government affair:

a.The affair is a public sector or concerns the public interest (Algemeenbelang)

b. There is direct or indirect government intervention or involvement in this matter

c. The legislation gives authority to the Government to manage (besturen) and regulate (regular) these affairs. (Ridwan, 2009)

In carrying out government duties, of course, the Government always takes legal action both in public law and in private law. Public legal actions are based on public law provisions, while private legal actions are based on civil law provisions. To take legal action in implementing government functions, the Government, of course, uses government instruments. (Ilmar, 2014)

e. Overview of the rule of law concept

Philosophers have long developed the concept of the rule of law from ancient Greece, such as Plato (429-374 BC) and Aristotle (384-322 BC). Aristotle's opinion provides an understanding that the state must stand above the law, guarantee justice for citizens. By stipulating placing the law as the highest thing (supreme) in the state, the administration of power in the state, especially the power of Government, must be based on law. In the conception of the rule of law, the power to run or administer Government must be based on the rule of law or the rule of law with the primary goal of realizing law and order in government administration.(Ilmar, 2014)

Government based on the law will give birth to a guarantee of protection of the community's fundamental rights. The interests between the Government that exercises state power and the people as subjects of state ownership can always be in accordance or line. Therefore, the submission of the concept of the rule of law as one of the legal foundations for Governance plays a significant role, not only as a corridor (limit) for government actions or actions but also as an essential reference and benchmark for assessment in Governance.

In the constitutional law literature, it is stated that there are two concepts of the rule of law that are always a reference. The concept of the rule of law, in the broader sense of "rechtsstaat" and the concept of the rule of law in the sense of "the rule of law," theother concepts of the rule of law like socialist legality."Islamic nomocracy" and "Pancasila state law," although concepts of the rule of law are the same. Namely aimed at providing legal recognition and protection for the community against an action or act of Government that is considered to have abused authority(detournement de pouvoir) or acted arbitrarily. authority (willekeur, onrechmatigeoverheidsdaad), but the historical background and legal system that supports these two concepts of the rule of law are very different

PhilipusM.Hadjo explained that in the literature, the Indonesian nation was trendy, known forusing the term the rule of law. However, according to him, it is still unclear to us what the rule of law is and is often combined or equated with the concept of the rule of law in the sense of 
"rechtsstaat."That is, "rechtsstaat" became popular and developed in Europe since the 17 th century and gained general recognition in the 19th century even though this idea has been around for a long time. As for the concept of "the rule of law" it became popular with the publication of a book by Albert Venn. Dicey (1885) with the title Introduction to the study of the law of the Constitution.(Hadjon, 2012)

As for the history and background of the development of the two concepts of the rule of law, they can be known and understood well so that they can be used as a reference and benchmark for assessment (measurement) in government administration. In addition, it is hoped that it will provide a basis for us to affirm the existence of an order or building of a state of the law in Indonesia, its form, and the paradigm of the rule of law in Indonesia. So far, there is a vague concept of the rule of law that is not used as the basis or basic framework for the nation and state. It should be enforced as to whether the basic framework of the rule of law that should be adopted is standardized to the conception of rachtsstaat or relies on the rule of law. It would be impossible to unite the elements of each of these countries of law, and even if it could be done, it would undoubtedly reject each other because it is based on the different nature and character of the law.

\section{RESEARCH METHODOLOGY}

\section{A. Method Of Collecting Data}

Methods The collection of legal materials is carried out by literature study to obtain data by studying various laws and regulations, books, and articles and journals obtained from papers or the internet related to the object of research.

\section{B. Data Analysis Method}

All data obtained were collected ultimately, then systematized for analysis. The method used in the analysis is descriptive qualitative with a deductive way of thinking, which starts from the legal regulations and is brought into the actual problem. Descriptive, namely analyzing data by describing in detail and precisely about a particular phenomenon related to the writing of this law. Qualitative, namely analyzing the presentation of the results of writing that have been systematized in a way that is obtained from legal theories and positive law to explain this legal research problem in the form of logical, scientific, and easy sentences to understand.

\section{RESULTS AND DISCUSSION}

\section{A. Conception of Discretion}

The division of authority is based on its nature; discretionary authority is one of them and binding authority and facultative authority. Although the discussion above has touched on a little about free authority or discretionary authority, in this discussion it will be explained in more detail related to discretionary authority, at least what will be explained is the meaning of discretionary authority, the purpose for which discretionary authority is used and lastly regarding the scope of the discretionary powers.

This will also be used as a limitation in this discussion, namely "the exercise of discretionary authority in the administration of government," or in other words, the discretionary authority described in this discussion is only limited to the implementation aspect, so that at that point when talking about Discretionary authority is no longer a matter of whether or not the authority can be used but on the right or wrong use of that authority.

It seems that this is quite reasonable, considering that now the discretionary authority itself has been regulated in positive Indonesian law, precisely in the UUAP. Then it is just a matter of how Government Agencies or Officials will use it in the administration of Government to realize the tasks and responsibilities given to them.

Understanding Discretion in terms of language, called wisdom, Discretion, judgment, freedom to determine. Discretion means freedom to determine or choose, depending on one's Discretion. Thus it can be found that what is meant by discretionary authority relevant to this 
discussion is the authority for public officials to act based on their discretion, based on their considerations, and the power of a person to choose to take or not to take action so that discretionary authority is defined as a means that provides space for the State Administration Agency or Government Official to take action without having to be fully bound by the law.

Discretionary authority means freedom of action for the Government in the administration of Government. Obstacles to the implementation of discretionary authority in government administration occur when discretionary authority is contradicted with the principle of government legality. Itsoften happens based on a simple logic that the principle of legality, which places more emphasis on government actions based on the law. In comparison, discretionary authority or free authority, which emphasizes government actions, should not be based on the law. From there, it is concluded; thus, implementing discretionary authority in the administration of an efficient and effective government to create government stability as expected will not work correctly. The Government has become very slow amid the many needs of the community that must be met immediately. The Government is still confined by various laws and regulations rigidly. Whereas the discretionary principle states that Discretion is a necessity in the concept of the welfare state as described in the discussion above. Such an attitude and mentality make the government administration very slow in responding to any changes and aspirations that develop in society, including the low power of service innovation to the public.That the two concepts are contradictory so that they are contradicted.

The exercise of discretionary authority in the administration of Government is a system of cooperation. As a system, there are elements, where each of these elements plays their respective roles so that the implementation of the discretionary authority can run as well as possible to achieve its goal of organizing people's welfare. These elements include government agencies or officials and law enforcers. Based on the results of interviews with several sources, it shows that there are several obstacles in the implementation of discretionary authority in government administration, namely the lack of harmony between these elements as mentioned above.

The UUAP and other related regulations do not specifically regulate a mechanism for testing government actions' forms or legal products based on discretionary authority. The form or legal product of the discretionary authority in state administrative law is usually known as the Policy Regulation. Efforts to realize the implementation of discretionary authority in government administration that is more efficient, effective, and productive require the awareness of Administrative Officers of their duties and functions. Related to this, there is a need to understand the concept of a secular legal state and the concept of discretionary authority by Government Agencies or Officials. When carrying out their duties and responsibilities, it is essential that government agencies or officials genuinely follow the concept of a secular law state and the concept of discretionary authority itself. The understanding of the concept of discretionary authority also influences the implementation of discretionary authority in government administration. Efforts to overcome practical obstacles as described above are the need for harmony of discretionary authority between Government Agencies or Officials. Law enforcers.

There is a need for a legal framework that guarantees this, starting from laws and regulations relating to how discretionary authority is exercised, then legislation relating to how to enforce discretionary authority when deviations occur both against laws and regulations and general principles of Government that good. Then in the internal Government itself, there is also a need for harmony between officials who use discretionary authority and officials who have the authority to supervise. So that in the exercise of discretionary authority itself, there is no contradiction with the supervision carried out by the internal Government. Then related to efforts to overcome the obstacles described above, several concrete steps need to be taken. First, theoretically, based on what has been described above, it can be understood that every government action must always have legal 
remedies as a form of legal protection for the community.

Considering that the policy regulation itself is a government action based on discretionary authority, when the two theories above are linked, the most appropriate institution to examine policy regulations is a court institution that exercises judicial power. Moreover, this needs to be on the agenda in legal politics as iusconstituendum. However, according to the author, the intended legal, political agenda is more about complementing the existing system, meaning that it is enough to complete the existing laws and regulations to provide more certainty in their implementation. In addition to this, to overcome the second juridical obstacle, an agenda in legal politics is needed to determine the nomenclature of policy regulations. It is necessary to facilitate the testing of policy regulations. It is considering that the test stone for policy regulations is different from the test stone for legislation. The testing of policy regulations uses the test stone for general principles of good Governance, while the test stone for testing legislation is the principles for forming laws and regulations.

\section{B. Restrictions on government authority}

The use of government authority in carrying out the Government's roles and functions and duties essentially needs to be limited. It isessential to do so that in government actions or actions based on government authority, there is always a concern that there will be an action or act of Government that abuses its authority and violates the law (detounement de pouvoir en onrechmatigeoverheidsdaad). In other words, the authority that has been given by law to the Government to be able to carry out an action or act of Government in principle is not expected to occur an action or act of Government that can harm the interests of the people. May deviate from the powers conferred on him by law.

For example, prelabeled authority is the authority to make decisions without asking for prior approval from any party or ex officio authority. It is called the authority in the context of making decisions taken because of its position. No one can resist it because it is legally binding on all people (who dare against it will be subject to criminal sanctions).

According to PrajudiAtmosudirdjo, government authority is an extraordinary power possessed by the Government (state administration), so that it cannot be carried out usually. authority from the Government. (Ilmar, 2014)

KoentjoroPoerbopranoto conveyed that the Government's actionsmust not conflict with laws and regulations or the public interest and must not be against the law (onrechtmatig), both formal and material in the broadest sense, and must not exceed or abuse the authority according to its competence. the use of government authority is intended to prevent acts or acts of abuse of authority or arbitrary acts carried out by the Government.(Poerbopranoto, 1975)

According to Philipus M Hadjon, every authority is limited by matter (substance), space (region; locus), and time (Tempus). Beyond these limits a government is an act without authority (onbevoegdheid) which can be in the form of onbevoegdheidratione material, onbevoegdheidratione Loco en onbevoegdheidrationetemporis. The procedure and substance. The existence of authority and procedure is the basis for the Government's formal legality, an action, or act. Based on this formal legality, the principle of praesumptioiustaecausa was born, in the sense that every action or act of the Government must be considered valid until there is an annulment for it. This principle becomes the ratio legis with the existence of regulatory norms that state that the lawsuit does not delay or hinder the implementation of government agencies or officials' decisions and the actions or actions or officials being sued. Its results in juridical defects concerning authority, procedure, and substance. Authority is always associated with every government action or act that requires that it be based on legal authority. (Hadjon, 2012)

Applying the principle of openness requires the Government to actively provide information to the public about an application for a 
plan. The Government's power is substantially limited in the sense that actions or actions, for example, the existence of authority to stipulate land and building taxes, are substantially limited according to the basic rules that are used as the basis to take action concerning or relating to the contents of the house or building.

In other words, the substance aspect concerns "what" and "for what" while the substance defects involve arbitrary actions, while the substance defects involve acts of abuse of authority. The concept of abuse of authority in administrative law is always paralleled with the concept of detournemen de pouvoir.PhilipusM. Hadjon mentions that the use of authority is not appropriate. In this case, the official uses the authority for other purposes that deviate from the objectives that have been given to that authority. Then it must be factually proven that government officials have used authority for other purposes. Abuse of authority is carried out consciously, namely transferring the purpose that has been given to the authority. The transfer of the purpose is based on personal interest or interest, either for his or for the benefit of others.

\section{Discretionary Limits in State Administrative Decision Making}

Discretion, also known as freiesermessen, comes from the word freies, which means free, free, not bound, and independent. Freiesis free, unbound, and accessible. At the same time,Ermessen means considering, assessing, guessing, and estimating. So FreiesErmessen means people who have the freedom to judge, suspect, and consider something. FreiesErmessen (discretionary) is then used in the field of Government as a means to provide space for state administration officials or agencies to take action without being fully bound by the law.

Some experts define Discretion, including S. PrajudiAtmosudirjo, which defines Discretion (UK), discretionary (France), freiesermessen (Germany) as the freedom to act or make decisions from authorized and obligatory state administration officials according to their own opinions. Furthermore, it is explained that Discretion is needed as a complement to the legality principle.
The law cannot regulate all kinds of case positions in the practice of daily life. for the benefit of the people. (Atmosudirjo, 1994)

Similar opinions were also expressed by SF Marbun and Mahfud MD as quoted by I GustiAyuApsariHadi, freiesermessen, namely the legal authority to intervene in social activities in order to carry out the tasks of carrying out the public interest; such as granting permits, revoking rights, establishing hospitals, and so on. Included in the definition of freiesermessen is making regulations on matters that have not yet been regulated or implementing existing regulations according to reality. Such coverage is called discretionary power. (Marbun \& MD, 2006)

Within the framework of the rule of law, Discretion is an act without limits. It means that there are elements that determine whether government officials, namely, can enforce Discretion:

a. Intended to perform public service duties.

b. It is an active attitude of the state administration.

c. The attitude of the act is allowed by law.

d. The attitude of the action was taken on its initiative.

e. The attitude of action is intended to solve significant problems that arise suddenly.

f. The attitude of the act can be accounted for both morally to God Almighty and legally.

The logical consequence of discretionary action is in legislation, namely the handover of legislative power to the Government. Under certain circumstances and in certain portions and levels, the Government can issue laws and regulations without prior approval from parliament. Droit function, namely the power to interpret a statutory regulation, but that does not mean that the Government can act arbitrarily. The Government is prohibited from taking actions that are detournement de pouvoir (doing something outside the purpose of the given authority) or onrechmatigeoverheidsdaad (acts against the law by the authorities), and the act can be prosecuted before a judge, either through the state administrative court or through the general court.(Marbun \& MD, 2006) 
According to Muchsan, as quoted by I GustiApsariHadi, the restrictions on the use of free ermessenare as follows:

a.The use of freiesermessen must not conflict with the applicable legal system (positive legal rules);

b. The use of freiesermessen is only intended for the public interest.

When it comes to state administrative law, this freiesermessen is given only to the Government or state administration to carry out ordinary and legal actions. When freiesermessen is embodied in a written juridical instrument, it is known as the rule of wisdom. In this case, the making of policy regulations becomes the authority of the Government (executive) to carry out its function, namely planning (beschikking) even though it has not been explicitly regulated.

Practically the discretionary authority of the state administration, which is then realized in a State Administration decision, contains two main aspects. First, the freedom to judge, which is objective, is the freedom to interpret the scope of authority formulated in the basic rules of authority. Second, freedom of judgment is subjective, namely the freedom to determine how and when the authority of the state administration is exercised. With this independent freedom from the Government, this is the basis for issuing a discretionary decision or Vrijebeschikking.(Ridwan, 2014)

As with the enactment of Law no. 30 of 2014 concerning Government Administration, the granting of Discretion carried out by government officials is strictly regulated in its articles. Discretionary restrictions can be seen in Article 24 of Law no. 30/2014, which reads:

Government Officials who use discretion must meet the following requirements:

a. following the purpose of the Discretion as referred to in Article 22 paragraph (2);

b. does not conflict with the provisions of laws and regulations.

c. following AUPB;

d. based on objective reasons.

e. Do not create a conflict of interest.

f. It is done in good faith.
From this formulation, it is clear that Government Officials exercising Discretion must consider the purpose of Discretion, the laws and regulations that form the basis of Discretion, freedom based on objective assessment, as far as possible avoiding conflicts of interest, good faith, and guided by General Principles. Good Governance from now onis referred to as AUPB.

AUPB can be used as signs for every discretionary decision issued by Government Officials, especially the principle of not abusing authority and the principle of public interest. Government policies will be categorized as deviant policies if they contain arbitrary elements. In addition, policies are considered deviant if they conflict with the public interest. The principle of the prohibition on abusing authority, including in making decisions, should not be based on considerations of personal interests or other purposes other than the purposes and objectives of the authority given to the official. Personal interests mean all interests that prioritize their interests and prioritize the interests of family, class, ethnicity, a particular religion, politics, economy, gender in making decisions.In other words, this principle provides an understanding that government officials should not act on something that is not their authority (excess de pouvoir).

The principle of public interest, according to Law no. 30/2014, contains elements:

1) prioritize public welfare and benefit.

2) in an aspirational, accommodating, selective, and non-discriminatory way

The principle of public interest is also contained in Law no. 23 of 2014 concerning Regional Government Article 58, which states, the implementation of regional Government is guided by the principle of state administration consisting of the public interest:

1) Furthermore, the elements contained in the principle of public interest according to the Regional Government Law are prioritizing public welfare.

2) In an aspirational, accommodating, and selective way. 
UU no. 30/2014 also affirms the limits of the scope of the use of Discretion as regulated in Article 23, as follows:

\section{Government Officials' Discretion} includes:

a. making decisions and/or actions based on the provisions of laws and regulations that provide a choice of decisions and/or actions.

b. Making decisions and/or actions because the laws and regulations do not regulate.

c. Making decisions and/or actions because the laws and regulations are incomplete or unclear,and.

d. Decision-making and/or action due to government stagnation for the broader interest.

\section{CONCLUSION}

The exercise of discretionary authority in the administration of Government is a logical consequence of Government, which is the power of the state given the task and responsibility to provide welfare for the community. However, this does not mean that discretionary authority can be used freely but must still pay attention to the limitations stipulated in the UUAP and AUPB.

The implementation of discretionary authority in the administration of Government has encountered several obstacles that have implemented discretionary authority in administration of government experience several problems such as the criminalization of government agencies or officials, the slow pace of government services to the community, which causes a decrease in the level of public trust in the Government, as well as violations of people's rights that often occur. By a Government Agency or Official. So, in the author's opinion, this kind of reality is a severe problem that should not be allowed to drag on, so efforts are needed to solve it.

To solve this problem, the author also discusses it in three parts, namely in terms of theory, practicality, and juridical aspects. This effort is not an easy thing because it will involve all parties. It started from the legislative, executive, and judicial powers. Through its legislative power, the legislature needs to schedule a legal framework to ensure the exercise of discretionary authority for Government Agencies or Officials and judicial powers in enforcing irregularities that occur as a result of the exercise of the discretionary authority. What is no less important is the need for the role of the community. The public also needs to understand the essence of the discretionary authority itself, at least to assess how discretionary authority is following applicable regulations or even deviates from existing rules. All of this is to ensure that the implementation of discretionary authority in the administration of Government runs efficiently and effectively in realizing prosperity for the community.

Within the framework of the rule of law, Discretion is an act without limits. The discretionary authority, which is then manifested in a State Administrative decision, contains two main aspects. First, the freedom to judge, which is objective, is the freedom to interpret the scope of authority formulated in the basic rules of authority. Second, freedom of judgment is subjective, namely the freedom to determine for yourself how and when the authority of the state administration is exercised. The enactment of Law no. 30/2014 Article 24 confirms that the limitation of discretionary authority by Government Officials can only be carried out in some instances where the legislation provides a choice, the applicable laws and regulations do not regulate it, the unclear legislation resulting in multiple interpretations, and government stagnation, namely concerning the livelihood of the people.

Practically the discretionary authority of the state administration, which is then realized in a State Administration decision, contains two main aspects. First, the freedom to judge, which is objective, is the freedom to interpret the scope of authority formulated in the basic rules of authority. Second, freedom of judgment is subjective, namely the freedom to determine how and when the authority of the state administration is exercised. With this independent freedom from the Government, this is the basis for issuing a discretionary decision or Vrije Beschikking. 


\section{REFERENCES}

Arbani, T. S. (2019). Penggunaan Dan Batasan Diskresi Dalam Pengelolaan Keuangan Daerah Di Indonesia. Jurnal Widya Pranata Hukum, 1(2).

https://doi.org/https://doi.org/10.37631/widyapranat a.v1i2.46

Atmosudirjo, S. P. (1994). Hukum Administrasi Negara,. Ghalia Indonesia.

Hadjon, P. M. (2012). Kebutuhan akan Hukum Administrasi Umum, dalam Hukum Administrasi dan Good Governance. Universitas Trisakti.

Hadjon, P. M., Lotulung, P. E., \& Laica, H. M. (2010). Hukum administrasi dan good governance. Universitas Trisakti.

Huda, N. (2011). Dinamika Ketatanegaraan Indonesia dalam Putusan Mahkamah Konstitusi. Universitas Islam Indonesia.

Ilmar, A. (2014). Hukum Tata Pemerintahan. Kencana Prenada Media Group.

Marbun, S., \& MD, M. (2006). Pokok-pokok Hukum Administrasi Negara. Liberty.

Mustafa, T., Purnama, E., \& Syahbandir, M. (2016). Penggunaan Diskresi Oleh Pejabat Pemerintah Untuk Kelancaran Penyelenggaraan Pemerintahan Daerah ( Studi Penelitian di Kabupaten Pidie). Jurnal Ilmu Hukum Pasca Sarjana Universitas Syah Kuala, 4(2).

Poerbopranoto, K. (1975). Sedikit tentang sistem pemerintahan demokrasi. Eresco.

Ridwan. (2009). Tiga Dimensi Hukum Administrasi dan Peradilan Administrasi. FH UII Press.

Ridwan. (2014). Diskresi dan Tanggung Jawab Pemerintah. Universitas Islam Indonesia.

Safudin, E. (2020). Politik Hukum Diskresi Indonesia, Analisis Terhadap Pembagian Kekuasaan Antara Pemerintah dan Legislatif. Jurnal Penelitian Islam, 14(01). https://doi.org/10.21154/kodifikasia.v14i1.1993

Susilo, A. B. (2015). The Meaning and Criteria of Discretion of Public Policy and/or Act of Public Officials in Good Governance Implementation. Jurnal Hukum Dan Peradilan,4(1). https://doi.org/http://dx.doi.org/10.25216/jhp.4.1.20
$15.133-152$

Wawan Riawan, \& Tjandra. (2011). Teory dan Praktek Peradilan Tata Usaha Negara. Universitas Atma Jaya.

Yuhdi, M. (2013). Peranan Diskresi Dalam Penyelenggaraan Pemerintahan. Urnal Likhitaprajna, 15(1). http://likhitapradnya.wisnuwardhana.ac.id/index.ph p/likhitapradnya/article/view/81 